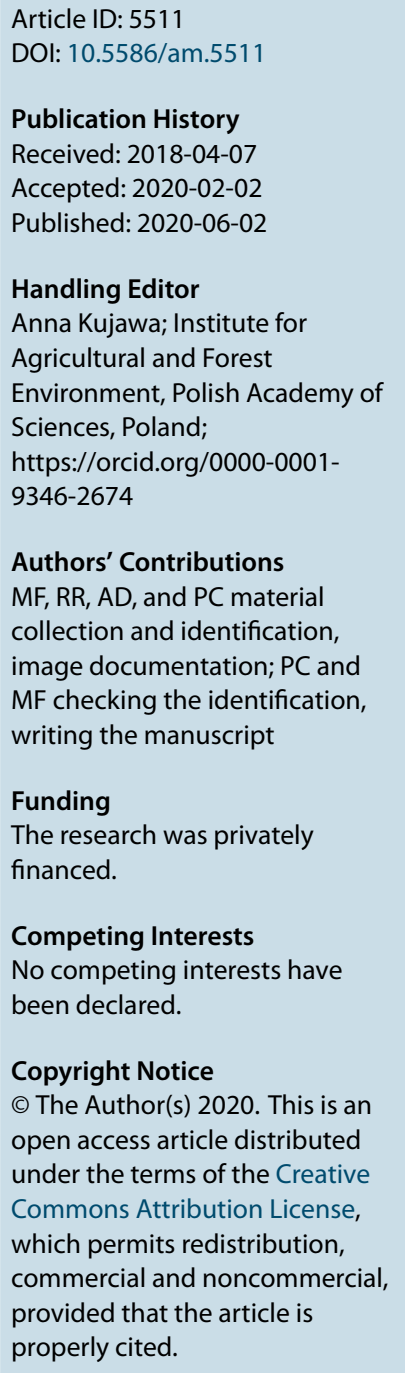

CHECKLIST

\section{New Record of Macrofungi for the Mycobiota of the Cieszyn Municipality (Polish Western Carpathians) Including New Species to Poland}

\author{
Piotr Chachuła ${ }^{1 *}$, Marek Fiedor $\mathbb{1 D}^{2}$, Ryszard Rutkowski ${ }^{3}$, \\ Aleksander Dorda ${ }^{4}$ \\ ${ }^{1}$ Pieniny National Park, Poland \\ ${ }^{2}$ Górki Nature Club Association, Poland \\ ${ }^{3}$ Independent researcher, Poland \\ ${ }^{4}$ Cieszyn Town Hall, Poland \\ *To whom correspondence should be addressed. Email: piotrekchacha@gmail.com
}

\begin{abstract}
In this paper, we present the results of mycological research carried out between 2015 and 2018 in the Cieszyn township, in the Silesian Foothills (Outer Western Carpathians). The list of 417 species of macrofungi from the Cieszyn area reported in our previous study, has been expanded further by the addition of 37 taxa found in the current study. Among these, the following deserve special attention: fungi that are new to Poland's mycobiota (six species: Bryoscyphus dicrani, Discina martinii, Elaphomyces aculeatus, Tuber brumale, T. foetidum, and Russula cerea), taxa subject to legal protection (four species: Disciotis venosa, Grifola frondosa, Mitrophora semilibera, and Sparassis brevipes), as well as fungi that are rare in Poland, included in national or regional red lists, and in the registers of rare and endangered species (24 species including Amanita echinocephala, Arrhenia retiruga, A. spathulata, Catinella olivacea, Elaphomyces maculatus, Hygrophorus discoxanthus, Ophiocordyceps entomorrhiza, Pluteus diettrichii, Tuber aestivum, and T. fulgens). This paper presents the distribution and location of 32 species of fungi along with a short description and illustration of the macro- and micromorphological features of select species and their habitats.
\end{abstract}

Keywords

Ascomycota; Basidiomycota; hypogeous fungi; mycorrhizal fungi; parasitic fungi; saprotrophic fungi

\section{Introduction}

Information about the various species of macrofungi that exist in the Cieszyn township should be considered relatively comprehensive. Between 2013 and 2015, the authors of this paper carried out extensive research in the area, which resulted in the inventarization of 417 species of fungi that grow in the administrative limits of the municipality (Chachuła et al., 2015). As a result of continued mycological exploration of the area in the following years, additional 37 species of fungi have been found. Among these are fungi that are protected and rare in Poland as well as species hitherto not reported in Poland. The article presents detailed description about their localities and ecology.

\section{Material and Methods}

The materials presented originate from the mycological collection and observation carried out in the Cieszyn area (within its administrative borders) (Figure 1) 


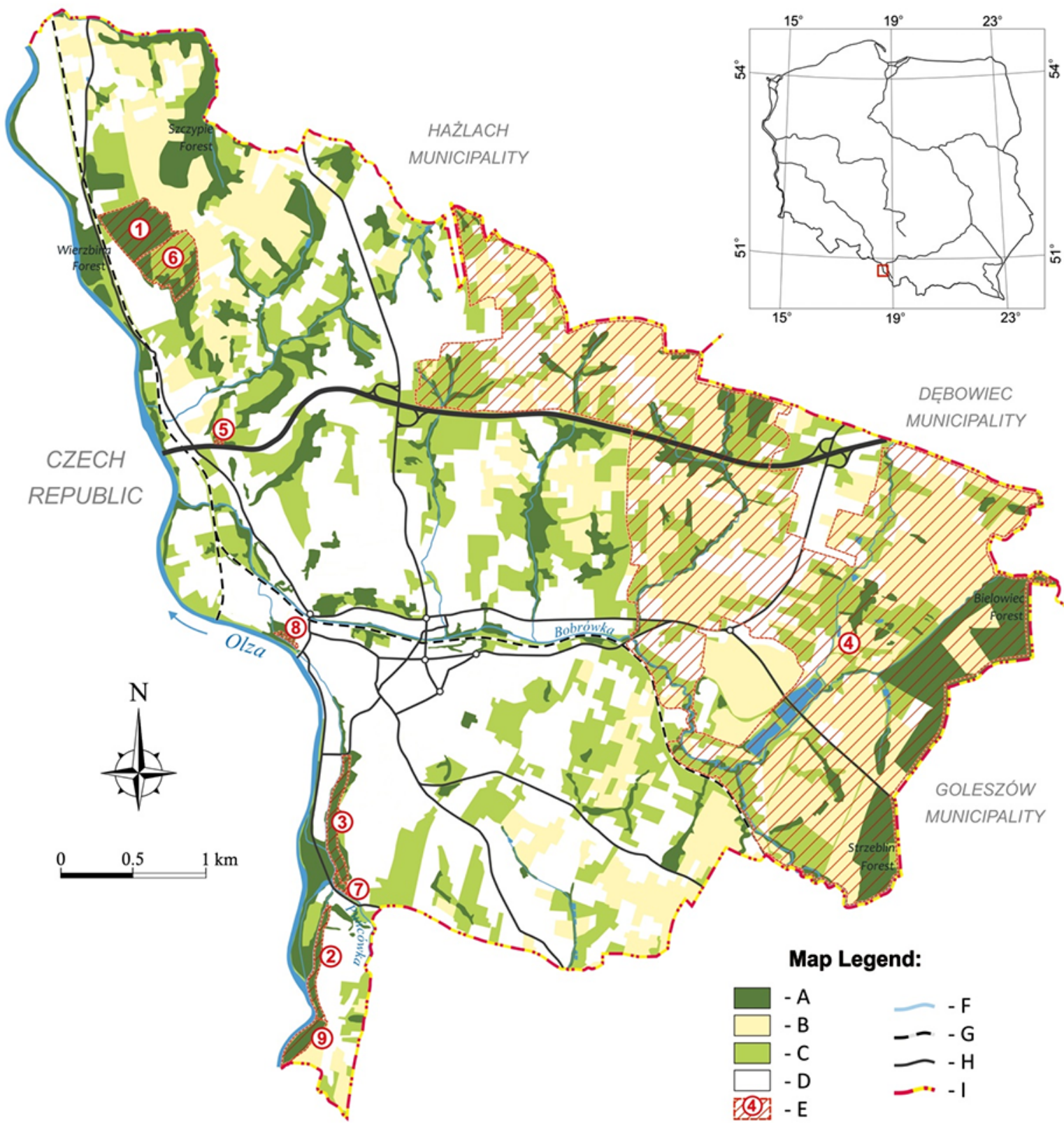

Figure 1 Map of Cieszyn municipality area. A - forests and tree stands; B - farmlands; C - meadows, pastures, orchards, and allotments; D - urbanized areas (industrial, service, and residential buildings); $\mathrm{E}$ - areal form of nature protection; $\mathrm{F}$ - surface water (streams, rivers, and ponds); G - railway; H - roads; I - commune border: 1 - "Kopce" nature reserve; 2 - "Lasek Miejski nad Olzą" nature reserve; 3 - "Lasek Miejski nad Puńcówką" nature reserve; 4 - "Cieszyńskie Pogórze" protected landscape area; 5 - documentation standout of teschenite opencast at Kręta Street; 6 - "Łąki na Kopcach" ecological use; 7 - "Eęg nad Puńcówką" ecological use; 8 - "Bluszcze na Górze Zamkowej" nature and landscape complex; 9 - "Lasek Miejski w Błogocicach" nature and landscape complex.

between 2015 and 2018. Mycological material was examined with a PZO (Polskie Zakłady Optyczne, Warsaw, Poland) Biolar light microscope with Nomarski interference contrast (NIC) and digital camera Delta Optical (Delta Optical, Warsaw, Poland) DLT-Cam PRO 10 MP (Figure 4A,E,F,H-J). Microscopic images (Figure 4B-D,G) were captured with an AxioScope A1 light microscope (Carl Zeiss, Jena, Germany) equipped with DIC system and digital camera AxioCam MRc5 in the Institute of Botany, Jagiellonian University in Kraków.

Microscopic slides were prepared from the dried fruiting bodies. For the new species of the Polish mycobiota, the measurements were made using 30 samples ( $n$ $=30$ ) for each characteristic structure (including spores, spines, asci, and cystyds). 
Spores were measured in side view, and without ornamentation and hilar appendix. Melzer's reagent, Congo red solution (in ammonia), and cotton blue solution (in water) were used for staining for observation of the micromorphological characters (Clemençon, 2009). Identification of the species was made according to mycological keys (Hansen \& Knudsen, 2000; Knudsen \& Vesterholt, 2008; Montecchi \& Sarasini, 2000). Nomenclature of the taxa followed the Index Fungorum (http://www.indexfungorum.org/). The specimen of Pluteus ephebeus was additionally identified using molecular methods at the Institute of Botany, Polish Academy of Sciences in Kraków. The species are presented in alphabetical order, according to the phyla Ascomycota and Basidiomycota. When a taxon is subject to species protection (Regulation of the Minister of Environment, 2014) or included in the red list of macrofungi endangered in Poland (Wojewoda \& Ławrynowicz, 2006) and in Polish Carpathians (Wojewoda, 1991), a square bracket with appropriate labeling follows the species name. It should be noted that the information on the occurrence included in the GREJ register (Kujawa et al., 2018), literature database (Kujawa, 2018), and in the checklists (Chmiel, 2006; Wojewoda, 2003) were also considered.

The description of localities include information about the localization including ATPOL squares (Komsta, 2016), habitat conditions including substrate or potential ectomycorrhizal plant partners observed in their surroundings, the number of fruiting bodies found, the date of observation, and individuals that collected and identified the specimens. The herbarium materials were deposited at the Jagiellonian University Herbarium in Kraków (KRA), as well as in P. Chachuła's private collection (PCh). In the case of rare hypogeous fungi, the authors have chosen not to provide more detailed information about the site/location of the species to protect and conserve the species.

The municipality of Cieszyn is situated in the western part of the Silesian Voivodeship. It covers an area of ca. 2,861 ha. According to the physicogeographical division of Poland (Kondracki, 2002) the municipality of Cieszyn belongs to the Cieszyn Foothills, which is the westernmost part of the Silesian Foothills mezoregion, and in turn a part of the Western Beskidian Foothills in the Outer Western Carpathians.

Geologically, the area is located within two unit - the Podśląska Nappe (in small part) and the Cieszyn Nappe. The latter consists mainly of the lower and upper Cieszyn schists divided by layers of Cieszyn limestone. In these layers, teschenites - intrusions of igneous rock - can also be found. In the hilly areas, the rock waste of Cieszyn Nappe form silty clay, roughing clay, sand, gravel, and loess. In the river valleys, coarse-grained gravels covered with alluvial mud soil, minerals, and organic mules may be found (Kasprowska \& Ciborowski, 2010).

Upland and hilly landscape dominates the topography of Cieszyn, $80 \%$ of which is covered by synanthropic systems (urban areas, farmlands, wastelands, and green areas). Relatively small areas, occupying less than $12 \%$ of the township, are overgrown with dispersed forest complexes and other wooded areas. In terms of composition, the forests comprise of pockets of fertile carpathian beech forests (Figure 2A), oak-hornbeam forests, riverside riparian ash-alder forests, and piedmont riparian ash forests. Less than $8 \%$ of the township area is occupied by meadows and pastures.

\section{Results}

During the mycological research conducted in the Cieszyn area between 2015 and 2018, 38 species of macrofungi were found, of which 37 had not been reported previously from the area. One species - Calvatia gigantea - was mentioned in the literature (Kujawa \& Gierczyk, 2011), but its presence was not confirmed during the comprehensive mycological research carried out previously in this area between 2013 and 2015 (Chachuła et al., 2015). Of the 38 fungal species, 15 belonged to the phylum Ascomycota and 23 to Basidiomycota. Of special interest are taxa not reported in Poland (six species), fungi subject to legal protection (four species), as well as rare taxa included in national or regional red lists and in the registers of rare and endangered species. 
Among the six taxa found in Cieszyn, and not mentioned in any prior publication from Poland, five species belong to Ascomycota - Bryoscyphus dicrani, Discina martinii, Elaphomyces aculeatus, Tuber brumale and T. foetidum, and one species belongs to hypogeous Basidiomycota - Russula cerea.

In addition, owing to continued research on the mycobiota of Cieszyn, four more protected species were observed within the city limits, including Disciotis venosa (subject to strict protection) and Mitrophora semilibera, Grifola frondosa, and Sparassis brevipes (under partial protection) (Regulation of the Minister of Environment, 2014). Thus, the number of species subject to legal protection and occurring in the administrative limits of the township increased to 10, including the species already reported from the area: Clavariadelphus pistillaris, Fistulina hepatica, Ganoderma lucidum, Hericium coralloides, Holwaya mucida, Trichoglossum hirsutum (Chachuła et al., 2015).

Among the species presented in this paper, 14 belong to taxa that are red-listed macrofungi of Poland (Wojewoda \& Ławrynowicz, 2006), including one species that has been given an extinct category (Ex) - Tuber aestivum, two endangered (E) species - Arrhenia retiruga and A. spathulata,four vulnerable (V) species Elaphomyces maculatus, Grifola frondosa, Mycena renati, and Sparassis brevipes, six rare (R) species - Auricularia mesenterica, Disciotis venosa, Gyroporus castaneus, Mitrophora semilibera, Pluteus ephebeus, and Stropharia pseudocyanea, and one in the I category (indeterminate) - Hebeloma radicosum.

Further, 25 species belong to taxa that are included in the GREJ register (Kujawa et al., 2018) and four (Auricularia mesenterica, Calvatia gigantea, Grifola frondosa, and Hebeloma radicosum) are also included in the red-listed macrofungi of the Polish Carpathians (Wojewoda, 1991).

Of note are taxa found relatively rarely in Poland, including: Amanita echinocephala, Catinella olivacea, Entoloma saundersii, Gymnopilus junonius, Helvella leucomelaena, Hygrophorus discoxanthus, Octospora leucoloma, Ophiocordyceps entomorrhiza, Pluteus diettrichii, and Tuber fulgens.

In the following section, we present a list of the 31 most interesting fungal species not previously reported from Cieszyn (and Calvatia gigantea), with their localities and details about their morphology and distribution. It should be noted that, due to their relatively frequent occurrence in Poland, six species are not included in the list, although they also belong in the group of 37 new species of mycobiota of Cieszyn, and these are: Agrocybe erebia (Fr.) Kühner ex Singe, Helvella acetabulum (L.) Quél., Hemipholiota populnea (Pers.) Bon., Mycena polygramma (Bull.) Gray, Pluteus romellii (Britzelm.) Lapl., and Strobilurus tenacellus (Pers.) Singer.

Abbreviations: ${ }^{*}$ - new taxon for Polish mycobiota; GREJ - a species included in the GREJ register; RLP - species listed on red list of macrofungi in Poland with appropriate the category of threat (Ex - extinct and probably extinct; $\mathrm{E}$ endangered; V - vulnerable; R - rare; I - indeterminate); RLK - species included in the red list of the macrofungi of the Polish Carpathians with appropriate conservation status ( $\mathrm{R}$ - rare); $\$$ - species protection ( $\mathrm{SP}$ - strict protection; $\mathrm{PP}$ partial protection); phot. - photography; initials of the authors: AD - Aleksander Dorda; AH - Anna Hreczka; MF - Marek Fiedor; MP - Marcin Piątek; PC - Piotr Chachuła; PM - Piotr Mleczko; RR - Ryszard Rutkowski; det. - identified; leg. collected; mat. - materials; unpb. - unpublished; obs. - observed; nat. res. - nature reserve.

\subsection{List of Recorded Species: Ascomycota}

\subsubsection{Bryoscyphus dicrani (Ade \& Höhn.) Spooner [*] (Figure 2B)}

Localities and Habitat. Cieszyn, landslide area near Błogocka Street, on the periphery of "Lasek Miejski nad Puńcówką" nat. res., DG00, few groups of ascomata on Bryum argenteum and $B$. caespiticium mosses, cocreating initial habitats on geotextile surfaces lined on exposed surfaces due to the mass movements, 2017-12-26, leg. RR and MF det. RR (PCh 1/26122017). 
Notes. Species thus far not reported from Poland. Occurs in Northern, Western, and Central Europe, but not common (Hansen \& Knudsen, 2000; Kirk \& Spooner, 1984; Knutsson, 2005). It is a parasite of moss. Its occurrence time is during the cold period of year, often from fall to spring.

Description of Examined Specimens. Apothecia flat, round, 1-3 mm in diameter, 1$2 \mathrm{~mm}$ thick, short-stipitate, white to pale pink. Stipe relatively thick, 1-2 mm in diameter, up to $2 \mathrm{~mm}$ long. Spores 10.7-16.7 $\times 5.3-9.3 \mu \mathrm{m}$ (on average: $14 \times 7.3$ $\mu \mathrm{m})$, smooth, fusoid and rhomboid. Asci with nonamyloid pore.

3.1.2. Catinella olivacea (Batsch) Boud. [GREJ] (Figure 3D)

Localities and Habitat. 1. Cieszyn, "Kopce" nat. res., DF90, in a beech forest formed on limestone soil, on the underside of a rotten trunk of a Fagus sylvatica, over a dozen ascomata, 2017-09-09, obs. \& det. MF and RR. 2. Cieszyn, "Lasek Miejski w Błogocicach" nature and landscape complex, DG00, in the undergrowth of riparian forest on a flood terrace of Olza River, several ascomata on fallen, rotten branch of deciduous tree, 2018-10-06, leg. \& det. MF and PC (KRA 2018-9).

Notes. Despite its global distribution, covering North and South America and Asia, it occurs in considerable dispersion and is rarely reported (Piątek, 2001). Data about occurrance in Poland comes from Wiśnickie Foothills ("Bukowiec" nat. res.), Ciężkowickie Foothills (St. Martin’s Peak in Tarnów), Knyszyńska Primeval Forest (Czołnowo area), Western Polesie (Ludwin Colony), Wigierski National Park, Wielkopolska region, and Bieszczady Mts (Gierczyk et al., 2019; Halama \& Romański, 2010; Miśkiewicz, 2000; Nita \& Bujakiewicz, 2004; Piątek, 2001; Snowarski, 2018).

3.1.3. Discina martinii (Donadini \& Astier) Donadini \& Astier [*] (Figure 2M, Figure 4A)

Localities and Habitat. Cieszyn, "Lasek Miejski w Błogocicach" nature and landscape complex, DG00, in the undergrowth of riparian forest on a flood terrace of Olza River, ascomata grew on fallen, rotten boughs and branches of deciduous trees, 2016-05-20 and 2017-05-17, leg. \& det. RR (KRA 2017-37).

Notes. Species not previously reported form Poland, though it has been observed in the Magurski National Park (AH - mat. unpb.). Known from a few countries in the Mediterranean (Spain, France, Italy, and Montenegro) (van Vooren, 2015). A similar species to Discina martinii is D. parma, which also has spore poles with of the fingerlike, however, $D$. parma has smaller spores $(26-30 \times 11.5-13.5 \mu \mathrm{m})$ (Hansen \& Knudsen, 2000).

Description of Examined Specimens. Apothecia brown, flat, round in outline wrinkled, $6(7.5) \mathrm{cm}$ in diameter, with short and veined stem. Outer layer clearly brighter from hymenium layer. Spores oval, 30-32 × 13-15 $\mu \mathrm{m}$, usually with one central and two smaller oil drops on the sides and of the fingerlike $1.5 \mu \mathrm{m}$ long appendages.

3.1.4. Disciotis venosa (Pers.) Arnould [§-SP, RLP-R, GREJ]

Localities and Habitat. 1. Cieszyn, "Lasek Miejski w Błogocicach" nature and landscape complex, DG00, riparian forest in Olza River valley, three ascomata on soil, 201604-26 and 2016-05-20, obs. \& det. RR. 2. Cieszyn, Wierzbina forest in Marklowice, DF90, three ascomata among Petasites hybridus complex, on the edge of riparian forest 2017-05-03, obs. MF, det. PC and RR.

Notes. In Poland, observed in small populations, mainly in the Polish Carpathian Mountains and their foothills, more rare in the Upper Silesia, Kuyavia, and Gdańsk Pomerania (Chmiel, 2006; Snowarski, 2018; Wojewoda, 2003).

3.1.5. Elaphomyces aculeatus Vittad. [*] (Figure 2D,E, Figure 4C,D)

Localities and Habitat. Cieszyn, DF90, in oak-hornbeam forest with Carpinus betulus and Acer campestre, formed on limestone bsoil, several ascomata, 2017-05-17, leg. \& det. RR (KRA 2017-33). 
Notes. Species not reported before in Polish mycological literature (Chmiel, 2006; Kujawa, 2018; Ławrynowicz, 1988; Skirgiełło \& Wosińska, 1963). For over a decade, it has been observed at another site in the Cieszyn Foothills - Tuł Mt area (RR - mat. unpb.). This hypogeous, ectomycorrhizal fungus is known from its few localities in western, central, and northern part of Europe, but some of the data is obsolete. It is considered as a relic species for deciduous and mixed forest with Corylus, Quercus, and Carpinus (Minter, 2013).

Description of Examined Specimens. Ascomata spherical, 1-4 cm in diameter, surrounded by a crust, consisting of closely interwoven hyphae, pink in color, strongly connected to the surface of the peridium. Peridium black and pink (if without crust), $1 \mathrm{~mm}$ thick, covered with acute pyramidal warts protruding above the surface of the crust. Gleba homogeneous powdery at maturity, blackbrown. Spores globose, 13.3-18 $\mu \mathrm{m}$ in diameter (average $15.6 \mu \mathrm{m}$ ), rusty brown, densely and evenly ornamented with small spines, $0.5-0.8 \mu \mathrm{m}$ high. The macroand micromorphological features of examined specimens correspond to other descriptions published (Paz et al., 2017).

3.1.6. Elaphomyces maculatus Vittad. [RLP-V, GREJ] (Figure 2C, Figure 4B)

Localities and Habitat. Cieszyn, DF90, in an oak-hornbeam forest with Carpinus betulus and Acer campestre, formed on limestone bsoil, over a dozen spherical ascomata, 2017-05-17, leg. RR, det. PM (PCh 1/17052017).

Notes. Very rare species known from two sites in the country, not recorded for several years (Ławrynowicz, 1988; Schroeter, 1889; Skirgiełło \& Wosińska, 1963).

Description of Examined Specimens. Ascomata spherical, 1-3 cm in diameter, sometimes deformed. Usually occurs in groups in the subsurface layer of soil. Ascomata are surrounded by loosely adherent mycelium, with a characteristic graygreen color. This fungus is characterized by black, suede peridium and relatively large spores (28-42 $\mu \mathrm{m}$ in diameter) (Paz et al., 2017).

3.1.7. Helvella leucomelaena (Pers.) Nannf. [GREJ]

Localities and Habitat. Cieszyn, "Wzgórze” gardening allotments area near Długa Street, DG00, two ascomata under the canopy of Pinus sylvestris, 2016-04-26, leg. \& det. RR (KRA 2016-93).

3.1.8. Mitrophora semilibera (DC.) Lév. [§-PP, RLP-R, GREJ]

Localities and Habitat. Cieszyn, Wierzbina forest, DF90, fertile, riverside riparian forest on limestone soil in Olza River valley, among Petasites under the canopy of Fraxinus excelsior and Salix sp., several ascomata, 2017-05-03, obs. \& det. MF.

3.1.9. Octospora leucoloma Hedw. [GREJ]

Localities and Habitat. Cieszyn, Kościelna Street region, DF90, on Bryum argenteum and B. dichotomum mosses, several ascomata, 2017-10-26, leg. \& det. RR (PCh $1 / 26102017)$.

Notes. Apothecia round, flat or slightly concave, $1-3 \mathrm{~mm}$ in diameter, without stipe. Coloring of apothecia ranges from yellow to orange. Ascomata occure singly and grow directly from moss. Octospora leucoloma is a parasitic species, growing on Bryum mosses which are widespread in Poland (Chmiel, 2006).

3.1.10. Ophiocordyceps entomorrhiza (Dicks.) G. H. Sung, J. M. Sung, Hywel-Jones \& Spatafora [GREJ] (Figure 3F,G)

Localities and Habitat. 1. Cieszyn, "Kopce" nat. res. DF90, beech forest, conidial form on the sterile part of the stroma growing from the body of Carabus sp. larvae, 201612-18, obs. \& det. RR. 2. Cieszyn, between Majowa and Kościelna streets, DF90, hornbeam-oak forest, two stromata growing from two bodies of Carabus sp. larvae, 2017-05-23, leg. MF, det. PC (KRA 2017-34). 3. Cieszyn, "Kopce" nat. res., DF90, beech forest, stroma growing from body of Carabus violaceus, 2017-08-24, obs. \& det. MF. 
Notes. Relatively rare taxon in Poland from the Cordycipitaceae family, parasitizing mainly on beetles from the Carabidae family and also on the Hemiptera of the Nabidae family. Typical stromata develop on beetles located in the subsurface layer of soil, several $\mathrm{cm}$ layer of soil. Perithecia of $O$. entomorrhiza develop on stromata. Observed on atrophied beetles in conidial form, also known under the synonymous name Tilachlidiopsis nigra (Bałazy, 1982). In Cieszyn, the perfect stages and conidial forms were observed developing on larvae and imago beetles of the Carabus (mainly Carabus violaceus).

3.1.11. Tuber aestivum Vittad. [RLP-Ex, GREJ] (Figure 2G, Figure 4G)

Localities and Habitat. Cieszyn, DF90, in hornbeam-oak forest with Carpinus betulus, Tilia sp., Acer campestre, and Quercus robur on limestone soil; several ascomata, shallowly buried in the soil, 2017-08-15, leg. MF and RR, det. PC and RR (KRA 2017-30).

Notes. Very rarely recorded fungus, until 2006 considered extinct (Wojewoda \& Ławrynowicz, 2006). Few sites concentrated in the south Polish highlands belt (Ławrynowicz et al., 2008).

Description of Examined Specimens. Ascomata irregularly globose, often with hollow base or slightly deformed, with diameter $2-10 \mathrm{~cm}$, recessed in the subsurface layer of soil. The outer surface of asomata is covered with conical, black, polygonal, furrowed warts 3-5 $\mathrm{mm}$ in diameter. Gleba brownish with a white-veined labyrinth. Mature ascomata have intense odor. Spores elliptic, surrounded by openwork regular reticulum are usually gathered in ascus (two-six spores).

3.1.12. Tuber brumale Vittad. [*] (Figure $2 \mathrm{H}$, Figure 4E)

Localities and Habitat. Cieszyn, DF90, hornbeam-oak forest with Carpinus betulus, Crataegus sp., and Acer campestre with poorly developed undergrowth, on limestone soil. Over a dozen ascomata in the subsurface layer of soil, 2016-12-18, leg. MF and RR, det. PC and RR (KRA 2016-90).

Notes. Not reported from Poland yet. Tuber brumale ist a fairly common in the Europe (Montecchi \& Sarasini, 2000). The red-brown color in the grooves between the verrucae distinguishes T. brumale from the other black Tuber found in Poland.

Description of Examined Specimens. Ascomata irregularely oval, 1-2 cm in diameter. Surfce black, covered with four-six angled, distinct warts, between which reddish colored fragments of the peridium were visible. Gleba light to dark brown, depending on the maturity of ascomata with white veins. Odor fruity, intense at maturity. Spores ellipsoid, $23.3-34 \times 15.3-23.3 \mu \mathrm{m}, \mathrm{Q}=1.5$ on average, covered with long-spiny ornamentation, $2-5 \mu \mathrm{m}$ long (up to $6 \mathrm{um}$ long in the case of spores formed singly in ascus).

3.1.13. Tuber foetidum Vittad. [*] (Figure $2 J, K$, Figure 4F)

Localities and Habitat. Cieszyn, DF90, single ascocarp found in the underground, in hornbeam-oak forest with Carpinus betulus, Tilia cordata, and Fagus sylvatica with poorly developed underground, 2017-08-15, leg. \& det. RR (KRA 2017-29).

Notes. Species of so-called white truffle, relatively rare reported from Europe (Montecchi \& Sarasini, 2000), not previously reported from Poland, but observed in the Stołowe Mountains National Park (PC - mat. unpb.). This species among the other truffles from the Tuber puberulum group distinguished by the morphology of peridium surface - brown plates on a yellowish background, and by pseudoparenchymatus peridium structure consisting of round cells (Montecchi \& Sarasini, 2000; Orczán et al., 2010). There is a light gleba in young ascomata, which becomes darker as it matures, becoming russet-brown with white veins. Fungus gives off an unpleasant odor, these traits also distinguish $T$. foetidum from another similar Tuber.

Description of Examined Specimens. The ascomata $1.5 \mathrm{~cm}$ in diameter with deformed, irregular surface and red-brown color of thin cover. Spores yellow-brown, elipsoid, $24.7-36.7 \times 15.3-26.7 \mathrm{~mm}, \mathrm{Q}=1.5$ on average, with reticulum $4-5 \mathrm{~mm}$ high. 
3.1.14. Tuber fulgens Quél. [GREJ] (Figure 3B)

Localities and Habitat. 1. Cieszyn, "Kopce" nat. res., under the canopy of Crataegus sp., Carpinus betulus and Fagus sylvatica, over a dozen ascomata, 2015-12-18, obs. MF and RR, det. PC and RR. 2. Cieszyn, east from the Motokrosowa Street, DF90, in fertile oak-hornbeam forest on limeston soil, in the immediate proximity of Carpinus betulus, several ascomata, 2017-03-25, leg. MF, det. PC (KRA 2017-40).

Notes. Species rare in Poland, reported for the first time in 2007 in the "Zielona Góra" nat. res. near Częstochowa (Lawrynowicz, 2009), next observed in several localities in Świętokrzyskie Voivodeship (Kujawa \& Gierczyk, 2011), the Cieszyn Foothills (Rutkowski et al., 2014), and Przemyśl Foothills (Gierczyk et al., 2018).

Description of Examined Specimens. Ascomata 1-3 cm in diameter, characteristic with intensive, orange color of wart peridium. Mature gleba takes on the cocoa color. Asci 120-130 $\times 90-100 \mathrm{~mm}$, containing one-four spores. Spores spherical or slightly ellipsoidal, $34-50 \times 30-40 \mathrm{~mm}$, with reticulum of wide alveolae with relatively high walls.

\subsection{Basidiomycota}

\subsubsection{Amanita echinocephala (Vittad.) Quél. [GREJ] (Figure 2l)}

Localities and Habitat. Cieszyn, "Kopce" nat. res., DF90, gap in the forest on limeston soil, under the canopy of Tilia sp., Carpinus betulus, and Fagus sylvatica, four basidiomata, 2017-09-06, obs. \& det. MF, PM, and RR.

Notes. Amanita species very rare in Poland, associated with warm deciduous forests with beech and oak, formed on limestone base rock. For the first time Amanita echinocephala was reported from Poland in 2008 (Świętokrzyskie Mountains and Kaczawskie Mountains) (Kasprowska \& Ciborowski, 2010).

Description of Examined Specimens. Basidiomata with pyramidal patches, densely arranged on the surface of gray-white pileus. White stipe, clearly thicker at the bottom, with the durable ring. Smell unpleasend, like a phenol. Spores ellipsoid, 9-12 $\times 6.5-8$ um. Description similar to other collections (Hagara, 2014).

3.2.2. Arrhenia retiruga (Bull.) Redhead [RLP-E, GREJ] (Figure 3E)

Localities and Habitat. Cieszyn, landslide area near Błogocka Street, on the periphery of "Lasek Miejski nad Puńcówką" nat. res., DG00, on Ceratodon purpureus moss, cocreating initial habitats on surfaces exposed due to the mass movements, ca. 30 basidiomata, 2017-12-23, leg. MF, det. PC and MF (PCh 1/23122017).

3.2.3. Arrhenia spathulata (Fr.) Redhead [RLP-E, GREJ]

Localities and Habitat. Cieszyn, Bielowiec forest, DG00, within plagiotropic moss Brachytecium salebrosum, which flat turf growing on rotten stumps, over a dozen basidiomata, 2016-09-25, leg. AD, det. PC (PCh 1/25092016).

3.2.4. Auricularia mesenterica (Dicks.) Pers. [RLP-R, RLK-R, GREJ]

Localities and Habitat. Cieszyn, "Lasek Miejski nad Puńcówką” nat. res., DG00, on a cut stump of Ulmus sp., aggregation of many, overgrown basidiomata, 2017-04-21, leg. $\mathrm{AD}$ and $\mathrm{MF}$, det. PC.

\subsubsection{Calvatia gigantea (Batsch) Lloyd [RLK-R, GREJ]}

Localities and Habitat. 1. Cieszyn, in the garden of kindergarten near Bolesław Chrobry Street, DG00, under the canopy of Picea abies, two basidiomata, 2016-0928, obs. \& det. MF. 2. Cieszyn, Bielowiec forest, DG00, two basidiomata in oakhornbeam forest, 2018-09-23, obs. \& det. AD and MF.

Notes. Species moderately widespread in Poland, but relatively rare reported in the Carpathians. Found once in Cieszyn (Kujawa \& Gierczyk, 2011), but not confirmed during the mycological research carried out in this area in 2013-2015 (Chachuła et al., 2015). 
3.2.6. Entoloma saundersii (Fr.) Sacc. [GREJ] (Figure 4J)

Localities and Habitat. Cieszyn, near Kościelna Street, DF90, within sunshine roadside slope, in the thicket of Crataegus sp., Rosa canina, and Corylus avellana, three basidiomata, 2016-05-08, leg. MF, det. PC (KRA 2016-91).

Notes. Spring fungus, reported from Świętokrzyskie Mts and from the Kurnik Arboretum (Łuszczyński, 2007; Rudawska \& Leski, 2013).

3.2.7. Grifola frondosa (Dicks.) Gray [§-PP, RLP-V, RLK-E, GREJ]

Localities and Habitat. 1. Cieszyn, oak-hornbeam forest near Dzika Street, DF90, one basidioma on rotting hornbeam stump, 2018-09-16, obs. MF, det. PC. 2. Cieszyn, Bielowiec forest, DG00, two basidiomata under an oak tree, 2018-09-16, obs. AD, det. PC and RR. 3. Cieszyn, Szczypie forest, DF90, one basidioma under an oak tree, 2018-09-18, obs. MF, det. PC.

Notes. Basidiocarps of $G$. frondosa grow at the base or close to the live or dead deciduous trees of Quercus, Fagus, and Carpinus. Basidiomata do not appear every year - despite the search the species was not observed in the Cieszyn area in the 2013-2017 seasons.

3.2.8. Gymnopilus junonius (Fr.) P. D. Orton [GREJ]

Localities and Habitat. Cieszyn, "Kopce" nat. res., DF90, group of over a dozen basidiomata at the base of dead, breaking up stump of Fagus sylvatica, 2017-10-02, leg. MF, det. PC (KRA 2017-36).

3.2.9. Gyroporus castaneus (Bull.) Quél. [RLP-R, GREJ]

Localities and Habitat. Cieszyn, oak-hornbeam forest near Dzika Street, DF90, several basidiomata on the soil formed from the stream deposits, 2018-09-16, leg. MF, det. PC (KRA 2018-8).

3.2.10. Hebeloma radicosum (Bull.) Ricken [RLP-I, RLK-R, GREJ] (Figure 3A)

Localities and Habitat. Cieszyn, "Kopce" nat. res., DF90, Fagus sylvatica with Tilia sp. old forest, several basidiomata, 2017-10-07, leg. \& det. PC and RR (KRA 2017-38, 2017-39).

Notes. Species not often observed in the country. Of the other Hebeloma, it is distinguished by a elongated root-like stipe base, occurence of ring on stipe and a very strong odor, resembling marzipan or bitter almonds (rarely described like a smell of fennel or prussic acid) (Halama et al., 2017). Documented are a few cases of the correlation between the presence of the fungus with the presence of underground nests of mice, moles, voles, or badgers (Sagara et al., 2006, 2008).

3.2.11. Hygrophorus discoxanthus (Fr.) Rea [GREJ] (Figure 3C)

Localities and Habitat. Cieszyn, "Kopce" nat. res., DF90, in beech forest, several basidiomata, 2017-10-07, obs. \& det. PC and RR.

Notes. The species was recorded so far only in the Tatra National Park, Bieszczady Mts, and Przemyśl Foothills (Gierczyk et al., 2018, 2019; Ronikier, 2012).

3.2.12. Mycena renati Quél. [RLP-V, GREJ]

Localities and Habitat. 1. Cieszyn, "Lasek Miejski w Błogocicach" nature and landscape complex, DG00, on fallen trunks and boughs of Fagus sylvatica and Fraxinus excelsior, 2016-05-20, obs. \& det. MF and RR. 2. Cieszyn, "Lasek Miejski nad Olzą" nat. res., DG00, on fallen trunks and boughs of Fagus sylvatica, 2017-04-21, obs. \& det. MF and RR. 3. Cieszyn, "Lasek Miejski nad Puńcówką" nat. res., DG00, on a surface of fallen trunk of Ulmus sp., several groups of basidiomata, 2017-04-22, obs. \& det. MF.

3.2.13. Octaviania lutea R. Hesse (Figure 2F, Figure 4I)

Localities and Habitat. Cieszyn, "Lasek Miejski w Błogocicach" nature and landscape complex, DG00, several basidiomata in the ground near Quercus robur and Carpinus betulus, 2017-08-22, leg. MF and PC, det. PC and PM (KRA 2017-32). 
Notes. Species previously reported from Poland only from Bieszczady Mts (Gierczyk et al., 2019), although in view of taxonomic revision published in 2016 (Paz et al., 2016), it is justified to verify specimens collected in the country, identified as Octaviania asterosperma Vittad, because in Poland occur only O. mutabilis and $O$. lutea. The basic differences between the two species concern on color of peridium: O. lutea - peridium usually thick, colored grayish white or yellowish, with faint spots bluish or greenish that, with manipulation, hardly redden Finally it is yellow ochraceous covered with blackish-gray fibrils. Peridium meat that does not redden to the cut; O. mutabilis - peridium generally thin, initially pure white with light bluish or greenish spots, which oxidizes quickly with vinous red manipulation and, more slowly, to blackish-gray. Peridium meat from pink color to the cut (Paz et al., 2016).

3.2.14. Pluteus diettrichii Bres. [GREJ]

Localities and Habitat. Cieszyn, "Kopce" nat. res., DF90, on dead wood of rotten stump of Fagus sylvatica, one basidioma, 2015-10-02, leg. RR and PM, det. PM.

Notes. Species observed in Poland only in the Kampinos National Park and Przemyśl Foothills (Gierczyk et al., 2018; Karasiński et al., 2015).

3.2.15. Pluteus ephebeus (Fr.) Gillet [RLP-R, GREJ]

Localities and Habitat. Cieszyn, Wierzbina forest, DF90, at the base of a Populus sp. trunk, two basidiomata, 2014-06-07, leg. MF and PM, det. MP.

Notes. The species in Poland observed on several localities (Kujawa, 2018; Wojewoda, 2003).

3.2.16. Russula cerea (Soehner) J. M. Vidal [*] (Figure 2L, Figure 4H)

Localities and Habitat. Cieszyn, "Kopce" nat. res., DF90, several basidiomata, Fagus sylvatica old forest, 2017-08-15, leg. \& det. RR (KRA 2017-28).

Notes. Species not mentioned in mycological literature from Poland (Kujawa, 2018; Wojewoda, 2003). Widely distributed in temperate and submediterranean regions of Europe, mycorrhizal species with Abies, Picea, Pinus, Castanea, Corylus, Fagus, and Quercus (Vidal et al., 2019).

Description of Examined Specimens. Basidiomata irregularly spherical, up to $1.8 \mathrm{~cm}$ in diameter, initially white, browning as they mature. Hymenophore loculate, with white-cream color, brown in mature basidiomata. Spores subglobose, yellowish at light microscope, 9.3-11.3 $\mu \mathrm{m}$ in diameter, ornamentation of slender, conical, and cylindrical amyloid spines of lenght $1.3-2.3 \mu \mathrm{m}$.

3.2.17. Sparassis brevipes Krombh. [§-PP, RLP-V, GREJ]

Localities and Habitat. Cieszyn, near Pikiety Street, DF90, in forested stream buffer, at the base of the living, Quercus robur, single basidioma, 2017-08-22, obs. \& det. MF i PC.

Notes. Species closely related with a similar species of the genus - S. spathulata. In a narrow view only individuals growing in Europe are included to the species (Petersen et al., 2015; Wang et al., 2004).

3.2.18. Stropharia pseudocyanea (Desm.) Fr. [RLP-R, GREJ]

Localities and Habitat. Cieszyn, near Rolna Street, DF90, on the edge of the pasture, 2017-10-28, obs. \& det. RR.

\section{Discussion}

Continued research on the mycobiota of the Cieszyn has contributed significantly to enhancement of knowledge and information about the regional mycological biodiversity, including rare or previously unreported taxa in the country. The discovery of 37 more fungal species in the Cieszyn area has increased the total number of mycobiota species studied area to 454 taxa (Chachuła et al., 2015). 



Figure 2 Selected fungi species found in the Cieszyn area. (A) Characteristic type of forest community for the Silesian Foothills calcareous beech forest in the "Kopce" nature reserve. (B) Group of Bryoscyphus dicrani ascomata on Bryum argenteum sporophytes. (C) Ascomata of Elaphomyces maculatus from the outside and in section. (D) Ascomata of E. aculeatus - with pink crust on the left side, without crust with black and pink peridium on the right side. (E) Elaphomyces aculeatus, cross section through the ascoma, with black acute warts within the peridium. (F) Basidiomata of Octaviania lutea in section. (G) Ascomata of Tuber aestivum from the outside and in section. (H) Ascomata of T. brumale from the outside and in section. (I) Young basidioma of Amanita echinocephala. (J,K) Tuber foetidum, surface (J) and cross section of the basidioma (K). (L) Basidiomata of Russula cerea from the outside and in section. (M) Ascoma of Discina martinii. Scale bars: (B-M) 10 mm. Photographs by M. Fiedor (A-C,F-L) and R. Rutkowski (D,E,M). 

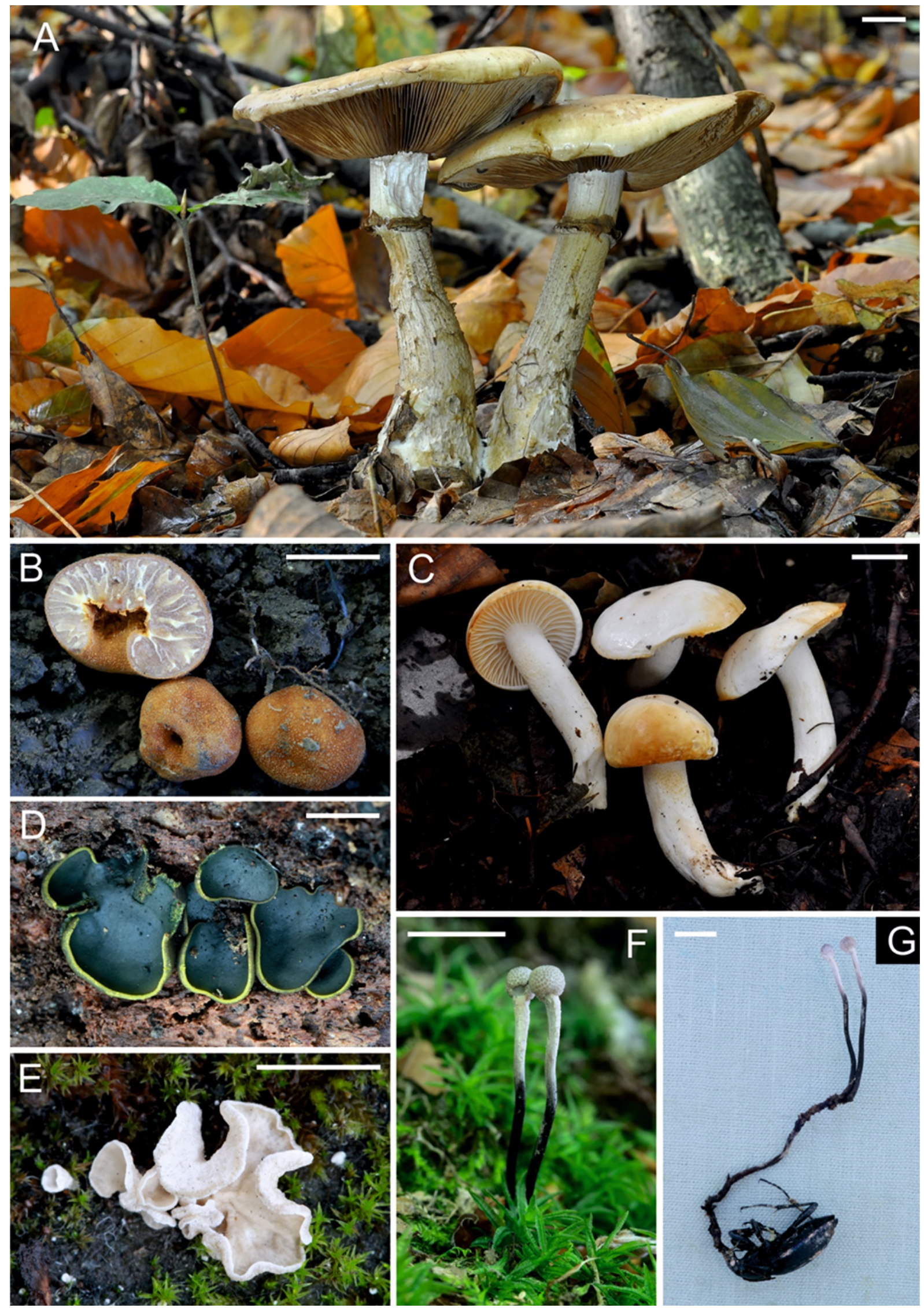

Figure 3 Selected species of rare fungi observed in 2016-2017 in Cieszyn. (A) Mature basidiomata of Hebeloma radicosum. (B) Ascomata of Tuber fulgens from the outside and in section. (C) Basidiomata of Hygrophorus discoxanthus. (D) Ascomata of Catinella olivacea. (E) Basidiomata of Arrhenia retiruga. (F,G) Stromata of Ophiocordyceps entomorrhiza growing from mummified body of Carabus violaceus. Scale bars: $10 \mathrm{~mm}$. Photographs by M. Fiedor (B,D-G) and R. Rutkowski (A,C). 

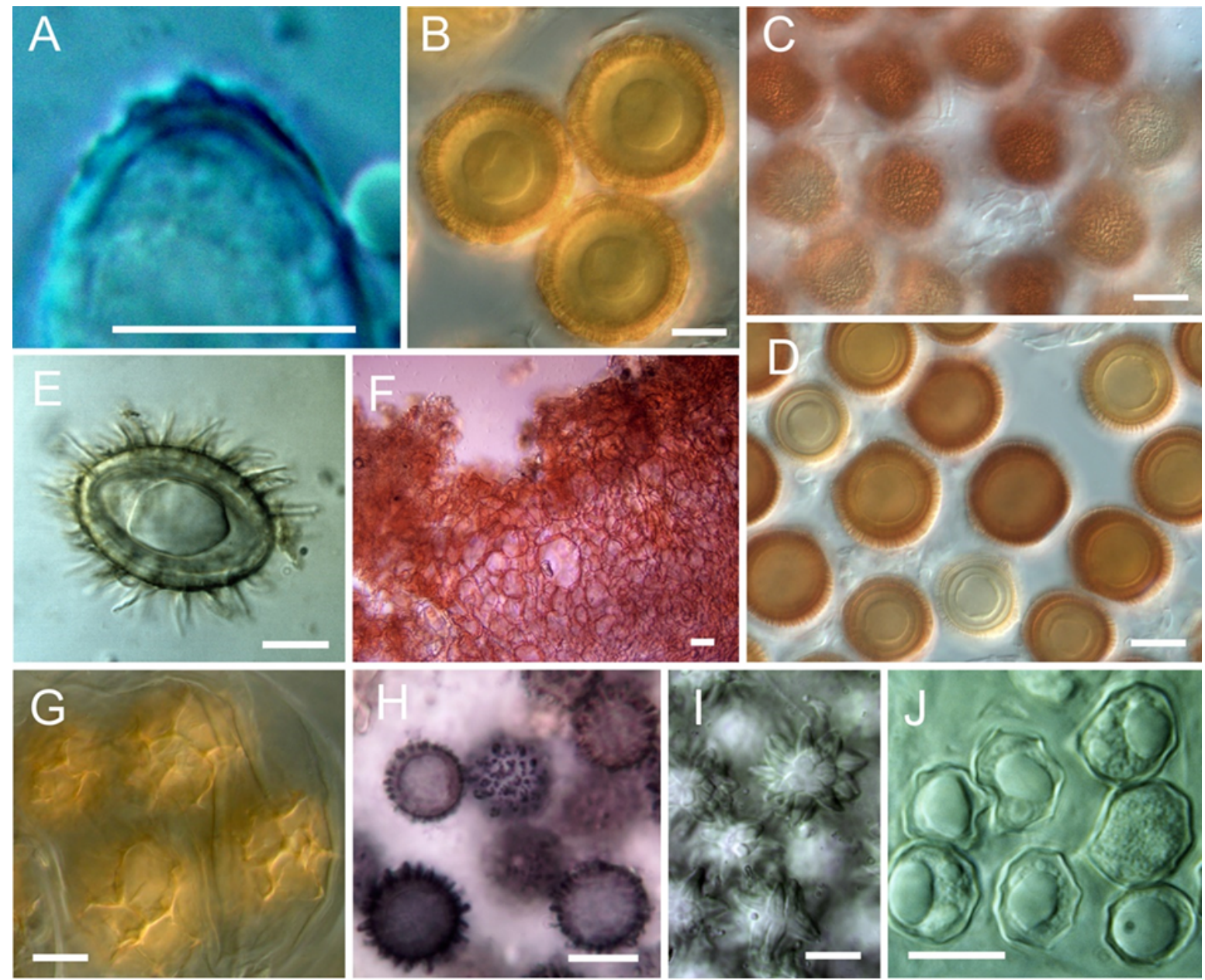

Figure 4 Micromorphological features of selected rare fungi species observed in Cieszyn. (A) Spore of Discina martinii. (B) Spores of Elaphomyces maculatus. (C,D) Spores of E. aculeatus with grainy surface from light microscope: Surface view (C) and optical section (D). (E) Spore of Tuber brumale, covered with dense spines. (F) Peridium of T. foetidum ascoma with pseudoparenchymatous structure (stained with Congo red). (G) Spores of T. aestivum covered with irregular reticulum. (H) Spores of Russula cerea with spiny, amyloid ornamentation. (I) Spores of Octaviania lutea with ornamentation in form of pyramidal-conic warts. (J) Polygonal spores of Entoloma saundersii. (A,I,J) Preparations in KOH; (B-E,G,H) stained in Melzer's reagent. Scale bars: $0 \mu \mathrm{m}$. Photographs by P. Chachuła.

Among them, 99 species belong to the phylum Ascomycota, 350 to Basidiomycota, and five to Mucoromycota.

The number of valuable species in the supraregional categories (protected, rare, and endangered) increased to 127 taxa. Among them are 13 species of fungi whose first national reports come from Cieszyn. Finding additional four protected fungal species has increased the total number of legally protected taxa to 10 (one with strict protection and nine with partial) (Regulation of the Minister of Environment, 2014). As a result of the comprehensive research of mycobiota of Cieszyn, the number of macrofungi taxa that figure in the red list of macrofungi in Poland (Wojewoda \& Eawrynowicz, 2006) that were observed in the township increased by 14 taxa and currently includes 82 such fungal species in Cieszyn (Ex - 1, E - 13, V - 21, R - 44, I - 3).

Another interesting aspect of the study that merits discussion is the relatively large number of hypogeous fungi that were found despite the small size of the forest area and the fact they were found accidentally - 15 hypogeous fungi were found within the administrative limits of Cieszyn, including four reported for the first time in Poland: Elaphomyces aculeatus, Tuber brumale, T. foetidum, and Russula cerea.

Despite the small size of the total area of the township analyzed (ca. 2,861 ha) and the relatively limited area that could be considered good for the development of mycobiota (nonurbanized) there were suitable microclimate, soil, and phytocoenosis 
conditions (mild-climate with high precipitation sum and higher average annual temperature, presence of limestone soil covered with deciduous forests) that supported the growth of such interesting and rarely recorded taxa in Europe, including: Amanita echinocephala, Elaphomyces aculeatus, E. maculatus, or $T$. brumale. These discoveries provide a reason of intensification of further mycological research in the remaining areas of the Cieszyn Foothills, which are abundant in various age-old complexes of beech, oak-hornbeam, and riparian forest growing in limestone soil. No such comprehensive mycological research has been conducted in the Cieszyn Foothills area, although several causative character publications have appeared in the recent times (Beczała, 2016; Chachuła et al., 2015, 2018; Krotoski, 2009; Rutkowski et al., 2014). Previous observations and reports clearly indicate that the Cieszyn Foothills are one of the national centers of mycological biodiversity.

Also worth mentioning is the fact that majority of the rare and protected macrofungal species found in the Cieszyn township were found in different types of nature protection areas including "Lasek Miejski w Błogocicach" nature and landscape complex, "Cieszyńskie Pogórze" protected landscape area, "Kopce," "Lasek Miejski nad Olza," and "Lasek Miejski nad Puńcówką" natural reserve. The occurence of the protected fungal species increases the natural value of the nature protection areas, and also indicates a properly functioning system of nature protection in the Cieszyn township.

\section{Acknowledgments}

Authors of this paper would like to thank Dr Sc. Adam Stebel for his consultation regarding the bryophyta species, Dr Sc. Piotr Mleczko for his help in identification in severalof the fungi species presented in this paper, and Marcin Piątek for carrying out the molecular tests that allowed for the identification of Pluteus ephebeus.

\section{References}

Bałazy, S. (1982). Supplementary notes to the biology of Cordyceps entomorrhiza (Dicks. ex Fr.) Link and the morphology of its conidial stages. Acta Mycologica, 18(2), 231-238. https://doi.org/10.5586/am.1982.019

Beczała, T. (2016). Naparstniczka stożkowata Verpa conica nowym gatunkiem grzyba dla Pogórza Cieszyńskiego [Verpa conica, a new fungus species for the Cieszyn Foothills]. Przyrodnik Ustroński, 15, 97-98.

Chachuła, P., Dorda, A., Fiedor, M., \& Rutkowski, R. (2015). Grzyby Cieszyna [Fungi of Cieszyn]. Urząd Miejski w Cieszynie.

Chachuła, P., Rutkowski, R., \& Mleczko, P. (2018). Presence and distribution of the rare ascomycete Stromatinia rapulum (Bull.: Fr.) Boud. (Sclerotiniaceae, Helotiales) in Central Europe with new localities from Poland. Nova Hedwigia, 106(3-4), 427-440. https://doi.org/10.1127/nova_hedwigia/2017/0443

Chmiel, M. A. (2006). Checklist of Polish larger Ascomycetes. W. Szafer Institute of Botany, Polish Academy of Sciences.

Clemençon, H. (2009). Methods for working with macrofungi: Laboratory, cultivation and preparation of larger fungi for light microscopy. IHW-Verlag.

Gierczyk, B., Kujawa, A., Szczepkowski, A., Ślusarczyk, T., Pachlewski, T., Chachuła, P., \& Domian, G. (2019). Macrofungi of the Bieszczady Mountains. Acta Mycologica, 54(2), Article 1124. https://doi.org/10.5586/am.1124

Gierczyk, B., Szczepkowski, A., Kujawa, A., \& Chachuła, P. (2018). Grzyby projektowanego Turnickiego Parku Narodowego i jego otuliny - wstępne wyniki badań [Fungi of the projected Turnicki National Park and it's buffer zone - preliminary research results]. In M. D. Boćkowski (Ed.), Projektowany Turnicki Park Narodowy. Stan walorów przyrodniczych - 35 lat od pierwszego projektu parku narodowego na Pogórzu Karpackim [The projected Turnicki National Park. The state of natural values after 35 years from the Park's first project] (pp. 176-227). Fundacja Dziedzictwo Przyrodnicze.

Hagara, L. (2014). Ottova Encyklopedie Hub [Otto's Encyclopedia of Fungi]. Ottovo Nakl. s.r.o.

Halama, M., \& Romański, M. (2010). Grzyby makroskopijne (macromycetes). In L. Krzysztofiak (Ed.), Śluzowce Myxomycetes, grzyby Fungi i mszaki Bryophyta Wigierskiego Parku Narodowego [Myxomycetes, Fungi and Bryophyta of the Wigierski National Park] (pp. 87-201). Stowarzyszenie “Człowiek i Przyroda”. 
Halama, M., Świerkosz, K., \& Chachuła, P. (2017). Pierwsze stanowisko włośnianki korzeniastej Hebeloma radicosum (Hymenogastraceae, Basidiomycota) w Sudetach Srodkowych [The first record of the rooting poison pie Hebeloma radicosum (Hymenogastraceae, Basidiomycota) in the Central Sudetes]. Przyroda Sudetów, 20, 113-120.

Hansen, L., \& Knudsen, H. (Eds.). (2000). Nordic macromycetes. Vol. 1. Ascomycetes. Nordsvamp.

Karasiński, D., Kujawa, A., Gierczyk, B., Ślusarczyk, T., \& Szczepkowski, A. (2015). Grzyby wielkoowocnikowe Kampinoskiego Parku Narodowego [Macrofungi of the Kampinos National Park]. Kampinoski Park Narodowy.

Kasprowska, K., \& Ciborowski, T. (2010). Zarys budowy geologicznej oraz wykorzystanie surowców skalnych na Pogórzu Cieszyńskim [Outline of geology and the use of rock resources in the Cieszyn Foothills]. In M. Szelerewicz \& J. Urban (Eds.), Materiały 44. Sympozjum Speleologicznego [Proceedings of the 44th Speleology Symposium] (pp. 9-17). Sekcja Speleologiczna Polskiego Towarzystwa Przyrodników im. Kopernika.

Kirk, P. M., \& Spooner, B. M. (1984). An account of the Fungi of Arran, Gigha and Kintyre. Kew Bulletin, 38(4), 503-597. https://doi.org/10.2307/4108573

Knudsen, H., \& Vesterholt, J. (Eds.). (2008). Funga Nordica. Agaricoid, boletoid and cyphelloid genera. Nordsvamp.

Knutsson, T. (2005). Två dåligt kända mossparasiter i den svenska svampfloran, Lamprospora carbonicola och Bryoscyphus dicrani [Two new species of bryoparasitic ascomycetes in Sweden - Lamprospora carbonicola and Bryoscyphus dicrani]. Svensk Mykologisk Tidskrift, 26(1), 52-55.

Komsta, Ł. (2016). Rewizja matematyczna siatki geobotanicznej ATPOL - propozycja algorytmów konwersji współrzędnych [ATPOL geobotanical grid revisited - a proposal of coordinate conversion algorithms]. Annales Universitatis Mariae Curie-Skłodowska, Sectio E - Agricultura, 71(1), 31-37.

Kondracki, J. (2002). Geografia regionalna Polski [Regional geography of Poland]. Wydawnictwo Naukowe PWN.

Krotoski, T. (2009). Chronione i rzadkie gatunki grzybów wielkoowocnikowych Góry Jasieniowa na Pogórzu Cieszyńskim [Protected and rare species of macrofungi of Jesieniowa Mountain of the Cieszyn Foothill]. Natura Silesiae Superioris, 12, 33-44.

Kujawa, A. (2018). Grzyby makroskopijne Polski w literaturze mikologicznej (wersja bazy: styczeń 2018) [The literature of the Polish macromycetes (database version: January 2018)]. Atlas grzybów Polski [Mushrooms and Fungi of Poland]. http://www.grzyby.pl/ grzyby-makroskopijne-Polski-w-literaturze-mikologicznej.htm

Kujawa, A., \& Gierczyk, B. (2011). Rejestr gatunków grzybów chronionych i zagrożonych w Polsce. Część IV. Wykaz gatunków przyjętych do rejestru w roku 2008 [Register of protected and endangered fungi species in Poland. Part IV. A list of species recorded in 2008]. Przegląd Przyrodniczy, 22(1), 17-83.

Kujawa, A., Gierczyk, B., \& Ślusarczyk, T. (2018). Rejestr gatunków grzybów chronionych i zagrożonych [Register of protected and endangered fungi species]. https://grzyby.pl/ rejestr-grzybow-chronionych-i-zagrozonych.htm

Ławrynowicz, M. (1988). Workowce (Ascomycetes). Jelaniakowe (Elaphomycetales), Truflowe (Tuberales). W. Szafer Institute of Botany, Polish Academy of Sciences; PWN.

Ławrynowicz, M. (2009). Four Tuber species accompanying T. mesentericum in natural sites in Poland. Anales del Jardín Botánico de Madrid, 66(S1), 145-149. https://doi.org/10.3989/ajbm.2227

Ławrynowicz, M., Krzyszczyk, T., \& Fałdziński, M. (2008). Occurrence of black truffles in Poland. Acta Mycologica, 43(2), 143-151. https://doi.org/10.5586/am.2008.018

Łuszczyński, J. (2007). Diversity of Basidiomycetes in various ecosystems of the Góry Świętokrzyskie Mts. Polish Botanical Society. https://doi.org/10.5586/mb.2007.001

Minter, D. (2013). Elaphomyces aculeatus. The Global Fungal Red List Initiative. Retrieved April 5, 2018, from http://iucn.ekoo.se/iucn/species_view/206042/

Miśkiewicz, A. (2000). Rare, threatened and new for Poland macromycetes found in the Bukowiec reserve (W Carpathians). Acta Mycologica, 35(2), 197-216. https://doi.org/10.5586/am.2000.021

Montecchi, A., \& Sarasini, M. (2000). Funghi Ipogei d'Europa [Hypogeous fungi of Europe]. Centro Studi Micologici, Associazione Micologica Bresadola.

Nita, J., \& Bujakiewicz, A. (2004). Nowe stanowiska rzadkich i zagrożonych grzybów wielkoowocnikowych w Wielkopolsce [New localities of rare and threatened species of macrofungi in the Wielkopolska region]. Badania Fizjograficzne nad Polska Zachodnia, seria B, Botanika, 53, 29-38.

Orczán, K. A., Turunen, O., Merényi, Z., Rudnóy, S., Bratek, Z., \& Shamekh, S. (2010). Tuber foetidum found in Finland. Mycotaxon, 114(1), 127-133. https://doi.org/10.5248/114.127 
Paz, A., Bellanger, J. M., Lavoise, C., Molia, A., Ławrynowicz, M., Larsson, E., Ibarguren, I. O., Jeppson, M., Læssøe, T., Sauve, M., Richard, F., \& Moreau, P. A. (2017). The genus Elaphomyces (Ascomycota, Eurotiales): A ribosomal DNA-based phylogeny and revised systematics of European "deer truffles". Persoonia, 38, 197-239. https://doi.org/10.3767/003158517x697309

Paz, A., Vidal, J. M., Lavoise, C., \& Moreau, P. A. (2016). Revisión taxonómica del género Octaviania (Boletales) en Europa [Taxonomic revision of the genus Octaviania (Boletales) in Europe]. Boletín Micológico de FAMCAL, 11, 101-138.

Petersen, R. H., Borovička, J., Segovia, J. R., \& Hughes, K. W. (2015). Transatlantic disjunction in fleshy fungi. II. The Sparassis spathulata - S. brevipes complex. Mycological Progress, 14, Article 30. https://doi.org/10.1007/s11557-015-1049-8

Piątek, M. (2001). Grzyby workowe polskich Karpat i ich przedpola. 1. Catinella olivacea i Rutstroemia bulgarioides [Ascomycota from the Polish Carpathians and their foreland. 1. Catinella olivacea and Rutstroemia bulgarioides]. Fragmenta Floristica et Geobotanica Polonica, 8, 251-255.

Ronikier, A. (2012). Fungi of the Sarnia Skała massif in the Tatra Mountains (Poland). W Szafer Institute of Botany, Polish Academy of Sciences.

Rozporządzenie Ministra Środowiska $z$ dnia 9 października 2014 roku, w sprawie ochrony gatunkowej grzybów (Dz. U. z 2014 r., poz. 1408) [Regulation of the Minister of Environment dated November 9, 2014 on the legally protected fungi (Journal of Laws, 2014, item 1408)]. (2014). http://prawo.sejm.gov.pl/isap.nsf/DocDetails.xsp?id= WDU20140001408

Rudawska, M., \& Leski, T. (2013). Symbioza mykoryzowa różnych gatunków wiązów [Mycorrhizal symbiosis of different species of elms]. In A. Biedunkiewicz \& M. Dynowska (Eds.), Abstracts of lectures and posters of the 56th Congress of the Polish Botanical Society (pp. 141-142). Wydawnictwo Mantis.

Rutkowski, R., Chachuła, P., Fiedor, M., \& Beczała, T. (2014). Grzyby i śluzowce [Fungi and Mycetozoa]. In R. W. Mysłajek (Ed.), Monografia przyrodnicza Góry Bucze [Monograph of the Bucze Mountains] (pp. 29-35). Gmina Brenna.

Sagara, N., Ooyama, J., \& Koyama, M. (2008). New causal animal for the growth of Hebeloma radicosum (Agaricales): Shrew, Sorex sp. (Mammalia, Insectivora). Mycoscience, 49(3), 207-210. https://doi.org/10.1007/s10267-008-0407-7

Sagara, N., Senn-Irlet, B., \& Marstad, P. (2006). Establishment of the case of Hebeloma radicosum growth on the latrine of the wood mouse. Mycoscience, 47(5), 263-268. https://doi.org/10.1007/s10267-006-0303-y

Schroeter, J. (1889). Die Pilze Schlesiens [The fungi of Silesia]. J. U. Kern’s Verlag. https://doi.org/10.5962/bhl.title.45927

Skirgiełło, A., \& Wosińska, A. (1963). O rozmieszczeniu jeleniaków (Elaphomyces) w Polsce [Elaphomyces distribution in Poland]. Państwowe Wydawnictwo Naukowe. https://doi.org/10.5586/mb.1963.008

Snowarski, M. (2018). Atlas grzybów Polski [Mushrooms and fungi of Poland]. https://www .grzyby.pl/

van Vooren, N. (2015). Gyromitra martinii (Pezizales), une espèce du sud de l'Europe? [Gyromitra martinii (Pezizales), a species of Southern Europe?]. Bulletin Semestriel de la Fédération des Associations Mycologiques Méditerranéennes, 47, 21-26.

Vidal, J. M., Alvarado, P., Loizides, M., Konstantinidis, G., Chachuła, P., Mleczko, P., Moreno, G., Vizzini, A., Krakhmalnyi, M., Paz, A., Cabero, J., Kaounas, V., Slavova, M., Moreno-Arroyo, B., \& Llistosella, J. (2019). A phylogenetic and taxonomic revision of sequestrate Russulaceae in mediterranean and temperate Europe. Persoonia, 42, 127-185. https://doi.org/10.3767/persoonia.2019.42.06

Wang, Z., Binder, M., Dai, Y. C., \& Hibbett, D. S. (2004). Phylogenetic relationships of Sparassis inferred from nuclear and mitochondrial ribosomal DNA and RNA polymerase sequences. Mycologia, 96, 1015-1029. https://doi.org/10.1080/15572536.2005.11832902

Wojewoda, W. (1991). Pierwsza czerwona lista grzybów wielkoowocnikowych (macromycetes) zagrożonych w polskich Karpatach [First red list of treatened macrofungi in the Polish Carpathians]. Studia Ośrodka Dokumentacji Fizjograficznej, $18,239-261$.

Wojewoda, W. (2003). Checklist of Polish Larger Basidiomycetes. W. Szafer Institute of Botany, Polish Academy of Sciences.

Wojewoda, W., \& Ławrynowicz, M. (2006). Red list of the macrofungi in Poland. In Z. Mirek, K. Zarzycki, W. Wojewoda, \& Z. Szeląg (Eds.), Red list of plants and fungi in Poland (pp. 53-70). W. Szafer Institute of Botany, Polish Academy of Sciences. 